\title{
International cooperation and mutual legal assistance in criminal matters in handling with transnational wildlife trafficking crimes in Vietnam
}

\author{
Duc Hanh Nguyen ${ }^{1 *}$ \\ ${ }^{1}$ Hanoi Procuratorate University (HPU), Duong Noi Street, 59/230 Y La, 1000, Hanoi, Viet Nam
}

\begin{abstract}
Wildlife crimes have been continuously increasing all over the world but particularly in ASEAN countries, and the criminals have employed more and more sophisticated tatics and strategies. Though many countries have introduced their own solutions to enhance the legal response and capacity to investigate, prosecute and adjudicate wildlife-related crimes, the results so far are under expectation. Vietnam has various types of wild, precious and rare flora and fauna; however, these numbers have rapidly decreased due to uncontrolled exploitation and illegal trade. Aiming to conserve and develop the nation's biodiversity, the Penal Code 2015 (amended in 2017) and the Criminal Procedure Code 2015 have new regulations that incorporate international conventions that Vietnam has acceded to. At the same time, Vietnam has become a transit nation employed by transnational criminal organizations, so that in order to tackle wildlife crimes effectively, it is significant to develop and sustain active international cooperation and mutual legal assistance in criminal matters among Vietnam and other countries in the region, as well as from all over the world. In that spirit, this article will concentrate on analyzing the current situation of wildlife crimes that has international elements; identifying roots of difficulties, challenges in dealing with this type of crimes in Vietnam as well as in the region; then proposing recommendations and solutions to improve the quality of handling transnational wildlife crimes for the sake of species conservation, environment and biodiveristy protection for humankind.
\end{abstract}

\section{Introduction}

Convention on International Trade in Endangered Species of Wild Fauna and Flora (CITES Convention) aims to ensure that humans' commercial activities do not threaten the survival of endangered wildlife species, and even some non-endangered ones. CITES controls trade based on one common legal framework which is applicable to all 183 member countries. International trade is based on a licensing system that is only granted under a number of certain conditions. Vietnam officially signed and ratified the convention in 1994.

\footnotetext{
*Corresponding author: hanhtrangvnncs1@gmail.com
} 
Wild fauna and flora are divided into three appendices I, II, III. Appendix I includes 530 species of animals and 300 species of plants threatened with extinction and the international trade of their specimens for commercial purposes is prohibited. Appendix II includes about 4400 species of animals and more than 28000 species of plants which although not necessarily now threatened with extinction but threatened with extinction without controlled trade. Appendix III includes about 160 species of animals and 10 species of plants that one nation requires the others to support to protect with controlled international trade (lower level of restriction than Appendix II) [25].

All acts that endanger aforementioned wildlife species such as trading, hunting, captiving, transporting, killing, illegally storing... individuals, parts or products of them that must be handled by criminal meassures are called wildlife crimes.

ASEAN is considered as one of hotspot for wildlife crimes since many countries share common borders and transportation by sea is easy. Vietnam is one ASEAN country that plays three roles in the illegal wildlife supply chain (Export/re-export - Import - Transit). [11]

In order to commit transnational wildlife crimes, offenders have formed organizations with close co-operation among accomplices to create a crimeline running through many countries with sophisticated tricks to evade detection and handling by law enforcement agencies. In fact, not only Vietnam but also other countries have encountered various difficulties and challenges in detecting, investigating and adjudicating wildlife crimes having foreign elements that are related to international cooperation and mutual legal assistance in criminal matters.

In order to enhance quality of detecting, investigating and adjudicating wildlife crimes in Vietnam and other nations for the sake of species conservation, environment and biodiversity protection for humankind, the author studies the four following main contents:

Developing an overview of the current situation of wildlife crimes in the world, in ASEAN and Vietnam to highlight issues such as tactics, purposes, scales... related to the international and transnational nature of crimes.

- Finding out and summarizing difficulties and challenges in handling organized and transnational wildlife crimes in terms of legal frameworks, species identification and evidence collection to prove crimes through mutual legal assistance...

- Identifying roots of difficulties and challenges in detecting and handling wildlife crimes having foreign and transnational elements.

- Proposing solutions and recommendations to overcome difficulties and challenges to enhance the capacity and effectiveness of detecting, investigating and handling wildlife crimes having foreign and transnational elements. Particularly, focusing on international cooperation and mutual legal assistance in criminal matters.

\section{Material and Methods}

This research is conducted through:

- Analyzing documents, reports, data and information on violations of wildlife crimes published by Vietnamese government agencies, namely: Vietnam CITES Management Authority, Ministry of Agriculture and Rural Development, the Supreme People's Court, the Supreme People's Procuracy, the National Assembly's Judicial Committee, Central Institute for Natural Resourses and Environmental Studies, Hanoi Procuratorate University...

- Using data from the Situational analysis of violations and law enforcement on wildlife in Vietnam, period 2013 - 2017 by the Wildlife Conservation Society Vietnam (WCS Vietnam). 
- Analyzing, assessing and using data from international seminars and proceedings on capacity-building for law enforcement agencies in combating wildlife crimes and a survey with 30 participants from the Southeast Asia, organized by the United Nations Office on Drug and Crimes (UNODC) and Hanoi Procuratorate University. The results are as below (fig. 1-4):

$$
\begin{array}{llllll}
0 \% & 20 \% & 40 \% & 60 \% & 80 \% & 100 \%
\end{array}
$$

Forest law/regulations

Customs Law

Special laws

Wildlife/game/hunting law/regulations

Penal Code

Specialized CITES law/regulations

Import/export laws/regulations

Protected species law/regulations

Biodiversity law/regulations

Protected areas law/regulations

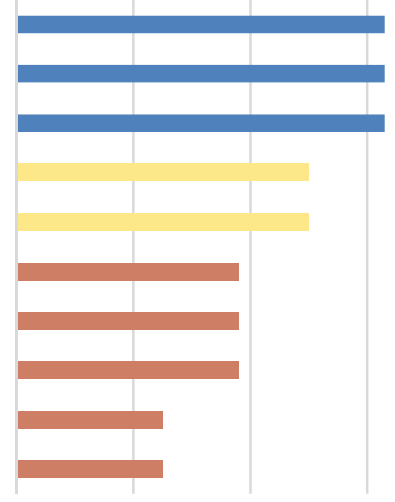

Fig. 1. The answers for question "What are the primary domestic laws used to combat wildlife crimes?" [21]

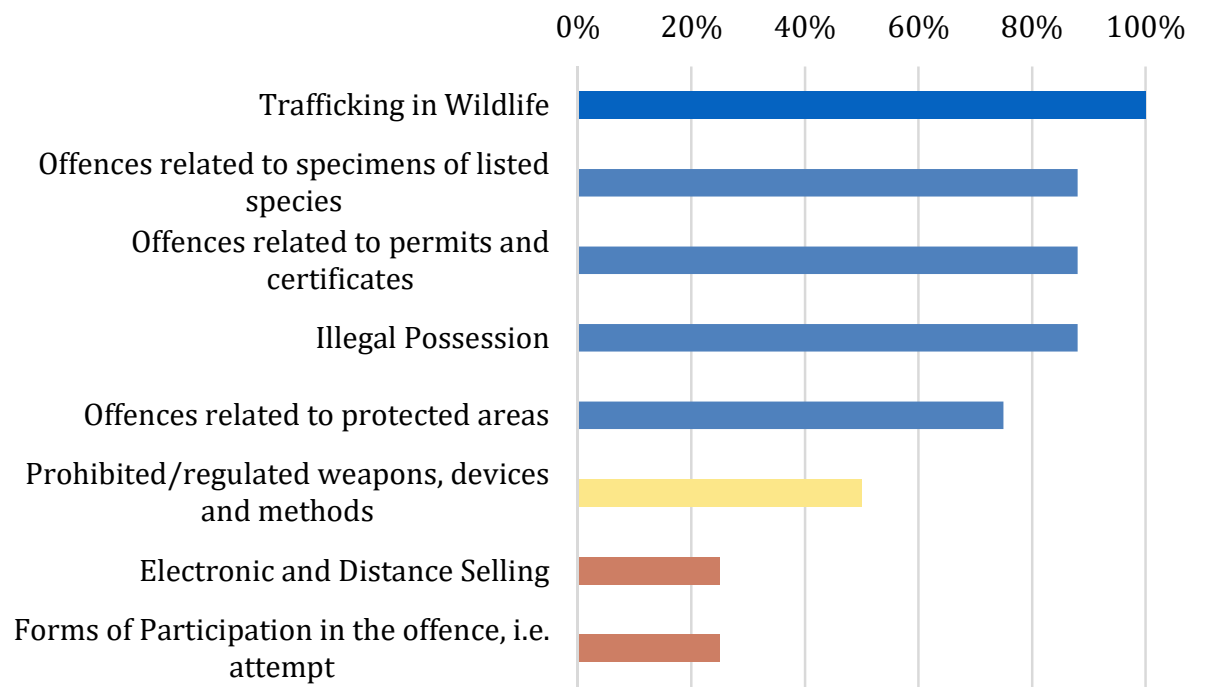

Fig. 2. The answers for question "Which of the following activities are considered offences under your domestic legislation?" [21] 


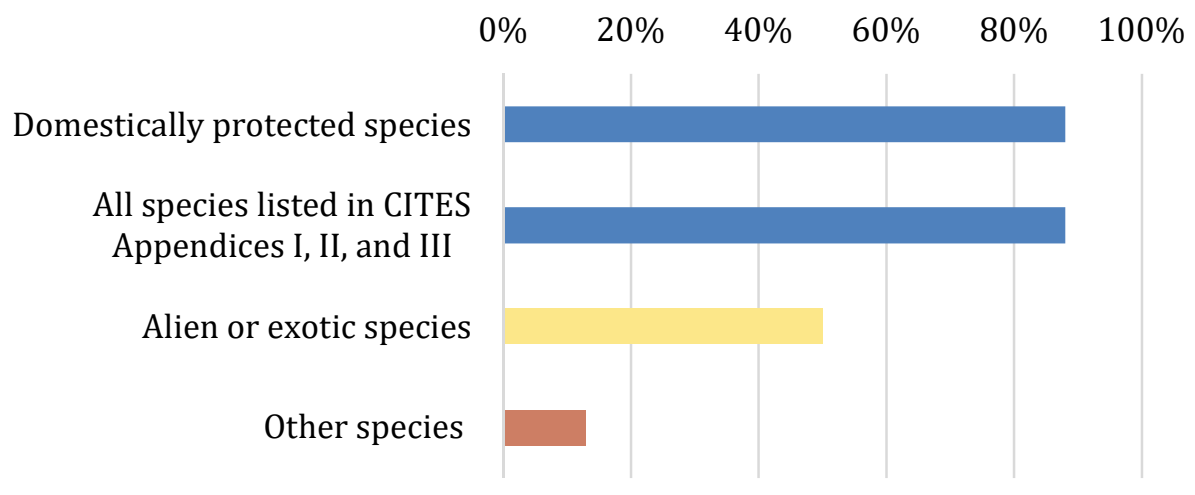

Fig. 3. The answers for question "Which species are protected?" [21]

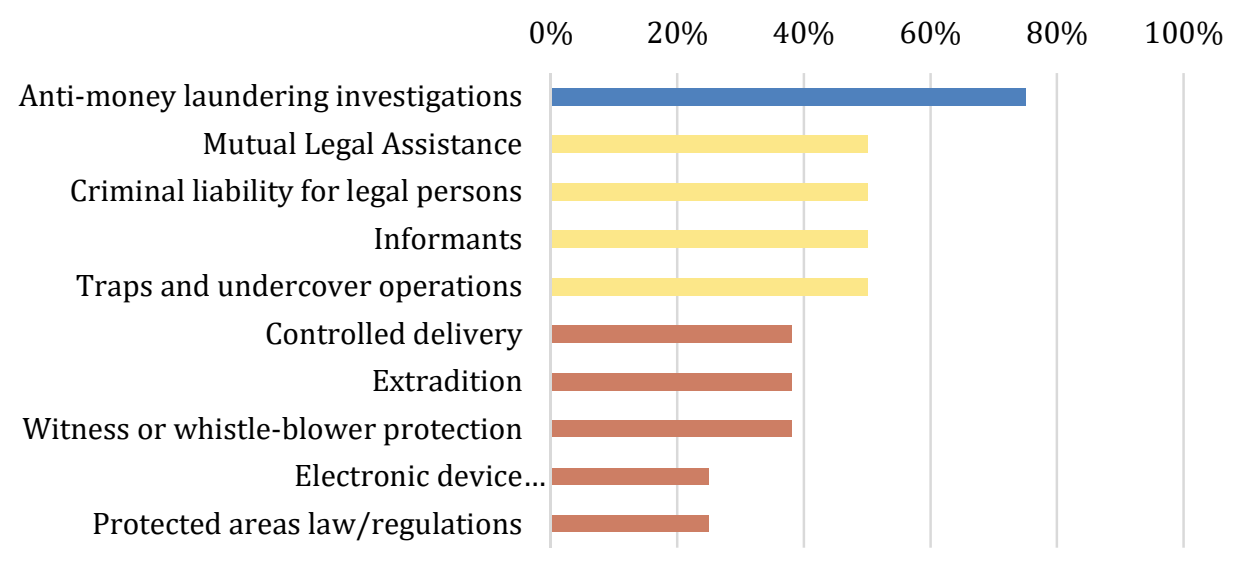

Fig. 4. The answers for question "What are predicate crimes and special investigations?" [21]

- Analyzing conference documents and proceedings on wildlife-related topics produced by different agencies, organizations and projects, either implemented independently or collaboratively, such as: Vietnam CITES Management Authority, Interpol, United State Agency International Development (USAID), US Embassy, the Supreme People's Procuracy, the Supreme People's Court, Hanoi Procuratorate University.

- In January and February, 2020, a group of 5 researchers (including the author) of Hanoi Procuratorate University conducted a research in which we accessed to case files, interviewed prosecutors who had directly solved wildlife cases having foreign elements from 2014 to 2019 at the People's Procuracy of Lang Son, Quang Ninh, Da Nang and Ho Chi Minh City. These are provinces and cities having borders with foreign countries or international airports. The results are as followed: Lang Son had 02 cases/01 defendant; Quang Ninh had 06 cases/0 defendant; Da Nang had 08 cases/09 defendants, Ho Chi Minh City had 19 cases/ 0 defendant. However, most of the cases are temporarily suspended (Lang Son 01 case, Da Nang 02 cases, Quang Ninh 06 cases, Ho Chi Minh City 19 cases). 


\section{Highlights of wildlife crimes in the world, in the region and in Vietnam currently}

\subsection{In the world}

Wildlife crimes including transportation, trade, captivity, hunting... is the fourth most lucrative illegal activity in the world, behind drug, weapons and human trafficking. According to United Nations Environment Programme (UNEP), wildlife crimes create illegal profit of approximately USD 7-24 billion annually [15].

Continuously increasing, wildlife crimes are becoming one of the most popular and illegal lucrative activities all over the world. This is a high-profit illegal activity with low risk for the legal frameworks for wildlife protection often appear to be incomplete. Besides, these crimes are often associated with other types of crimes such as money-laundering. [23]

Wildlife crimes also impact adversely to the nations' economies, for the crimes often associates with tax evasion and has negative influences on tourism and ecosystems. [17]

The exposure to and interaction with alien animals that are transported, traded, bred, hunted... without proper veterinary care, inspection and quarantine may lead to dangerous disease outbreaks involving human and domestic animals that ultimately affect every nation's economy. [27]

Therefore, wildlife crimes must be prevented by all countries. Particularly, widllife originating from underdeveloped countries are transported and traded to other countries of better economicconditions where people have good income and the habit of using wildlife products for food or medicine.

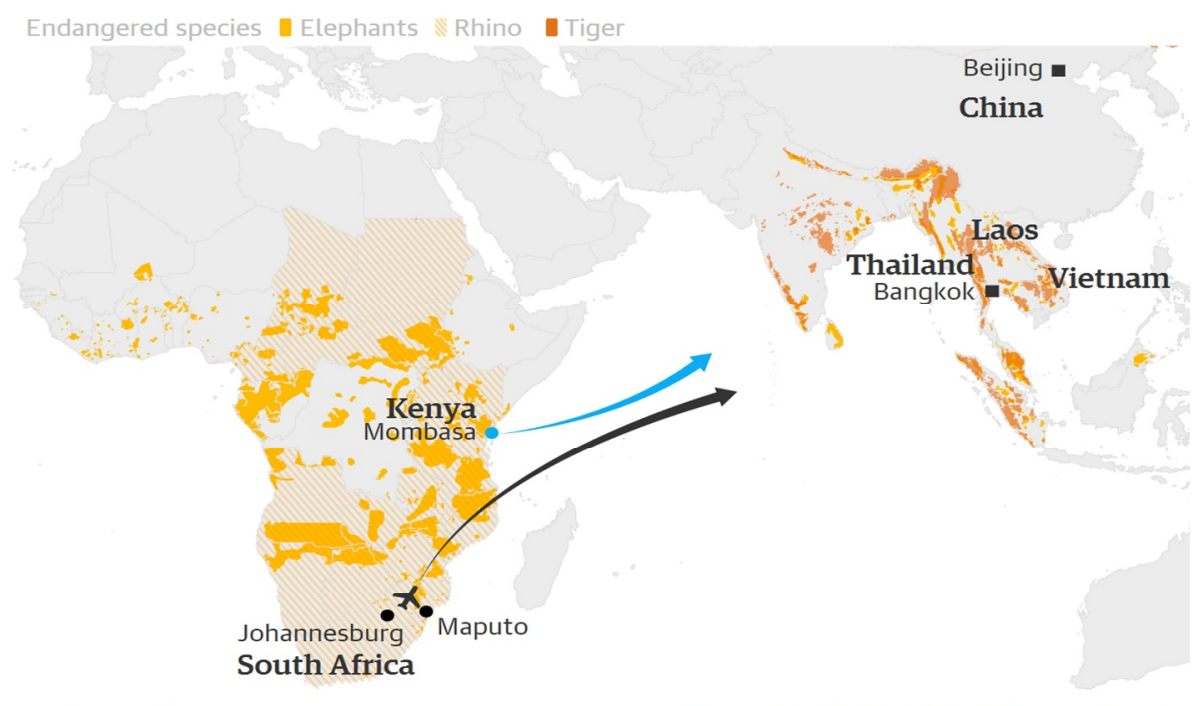

Guardian graphic

Source: The IUCN Red List of Threatened Species

Fig. 5 The Illegal map of wildlife trade from Africa to Asia (Source: IUCN Red List of Threatened Species) [16]

The international illegal trade in wildlife is currently experiencing the impact of a number of policy innovations. While it is probably still too early to say, tightening national and international controls appear to be showing positive results with regard to some of the best known illegal wildlife markets [20] 


\subsection{Overall situation in ASEAN}

ASEAN is a hot spot for wildlife consumption as well as the main destination of illegal wildlife transportation, trade, captivity, hunting with an estimated value of more than USD 2,5 billion annually [22]. Most illegally transported and traded wildlife originate in the region; however, the sharp decline of biodiversity in the region and demanding for rare and strange wildlife species has been promoting the illegal wildlife transportation, trade, captivity, hunting transcontinentally. That leads to negative impacts to ecosystem of countries where are the origin of wildlife like African ones.

Curently, China and Vietnam are two of the largest wildlife trade markets in the world, which is the operating area of organized crime groups. Besides that, Vietnam, Singapore, Thailand, Laos and Malaysia are known as transshipment points in wildlife traficking in which the two latter countries is becoming favourite place of offenders. Other important transshipment areas include the Philippines, Indonesia and Cambodia. The masterminds of crime network operating throughout Asia are in Vietnam and China [24].

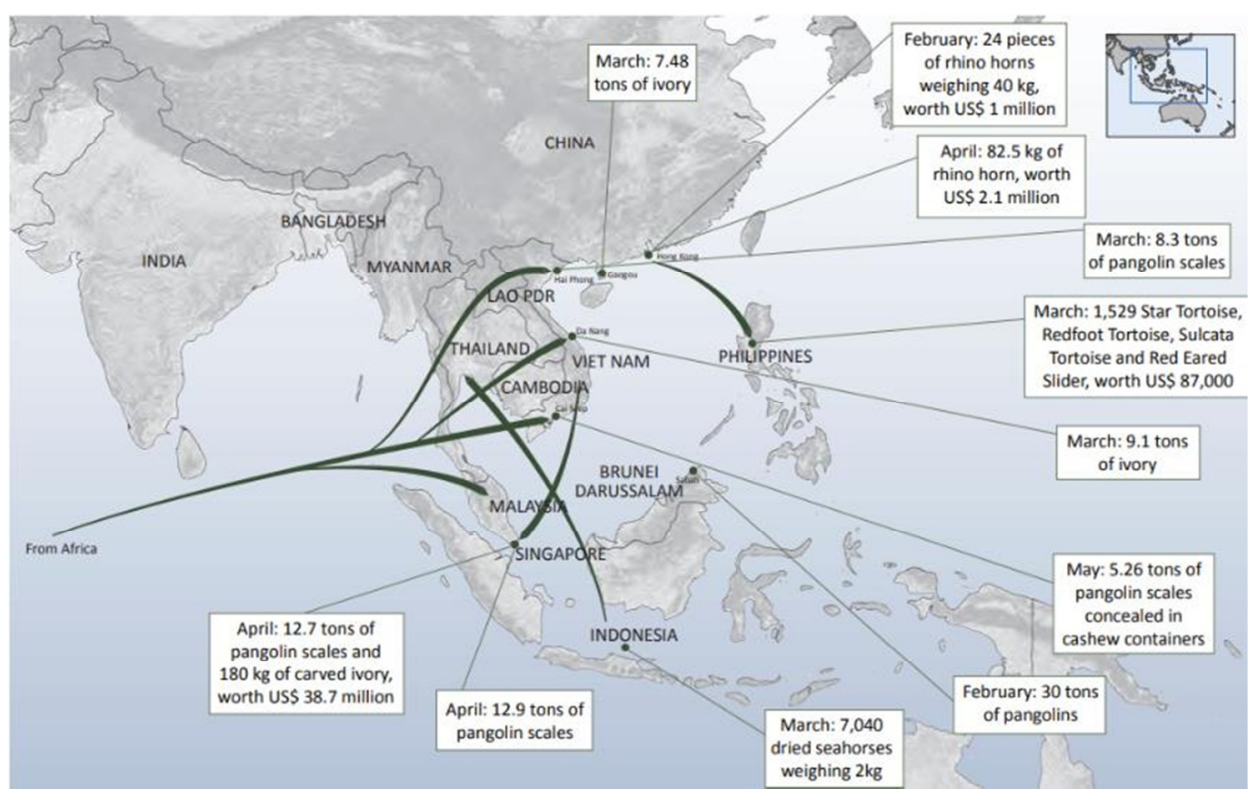

Fig. 6 Major seizures of illicit wildlife products in Southeast Asia and China, first half of 2019 [24]

According to the records of ASEAN Secretary, a number of outstanding criminal cases recently discovred: [11]

+ In 2018, Campuchia detected and arrested 129 wildlife cases, confiscated 6,477 wild animals; Laos confiscated 55,3 kg of ivory, 01 rhino horn, $266 \mathrm{~kg}$ of snake, $0,6 \mathrm{~kg}$ of pangolin and some tiger bones.

+ In December of 2018, Indonesia arrested 506 pig-nosed turtles at Merauke seaport.

+ On December 16, 2018, Thailand arrested 22,3 kg of ivory at Nakhon Phanom and on August 25, 2018 they arrested 162 living pangolins and $50 \mathrm{~kg}$ of pangolin scales.

+ On April 03, 2019 and April 08, 2019, Singapore arrested 12,9 tons and 12,7 tons of pangolin scales, respectively.

\subsection{Overall situation in Vietnam and legal framework}

Overall situation in Vietnam. According to statitics of Wildlife Conservation Society 
(WCS) in Vietnam, between 2013 and 2017, Vietnamese law enforcement agencies detected and arrested 1.504 wildlife cases; at the same time, more than 180 wildlife species had been illegally transported, traded, bred, hunted... Specifically, wildlife trafficking cases related to snake accounted for the biggest percentage - 20,55\% (309/1.504 cases), followed by tortoises and turtles - 10,31\% (155/1.504 cases), birds - 8,58\% (129/1.504 cases), pangolins - 7,38\% (111/1.504 cases)... Wildlife cases related to elephants and rhinos made up smaller proportion of the total number of wildlife violations seized and confiscated by Vietnamese law enforcement agencies which were 3,39\% (51/1.504 cases) và 2,73\% (41/1.504 cases), respectively [27]

The number of cases related to some species not originating from Vietnam like rhino, elephant, pangolin accounted for 13,5\% (203/1.504) of total violated cases, $7,43 \%$ $(1.949 / 26.221)$ of arrested individuals and $44,64 \%(18.450 / 41.328 \mathrm{~kg})$ of the total seized wildlife, recorded during the period of 2013 and 2017.

About the origin, a half of detected, arrested and possessed wildlife came from Africa (19/38). The highest percentage belonged to Angola which accounted for 26,32\% (5/19) [27]

Another survey conducted by TRAFFIC in Hanoi in 2007 showed that the majority of the community lacked knowledge about wildlife protection laws as well as the environmental impacts of wild plant and animal consumption [1]

Numerous studies and surveys have been conducted in Vietnam in recent years to understand the attitudes and behaviors of wildlife consumers, and to address demand reduction efforts. For example, TRAFFIC's 2013 study on rhino horn consumers in Vietnam showed that buyers of rhino horn are usually middle-aged or older women, educated, and often buying for others; while rhino horn users are usually rich men aged 40 and over [18]

Recently, wildlife crimes have not reduced in nature and scale as shown in following data presented by Vietnamese authorities: [11]

+ On January 25, 2019: arrested $500 \mathrm{~kg}$ of ivory and 1,5 tons of pangolin scales in wood containers at Hai Phong seaport;

+ On July 27, 2019: arrested $130 \mathrm{~kg}$ of rhino horns covered by plaster at Noi Bai airport;

+ On March 26, 2019: arrested 9,1 tons of ivory in wood containers at Da Nang seaport;

+ On April 16, 2019: detected and arrested 11 pangolins (58,2kg) at Nghe An; on April 18, 2019 detected and arrested 39 pangolins (136kg) at Hung Yen; on July 23, 2019: arrested 10 individuals of Java pangolins in Quang Ninh;

+ In December of 2014: detected illegal possession of 8 tons of sea turtles and sea turtle corpses in Nha Trang, Khanh Hoa;

+ In November of 2015: detected illegal possession of 9 tons of box turtles and sea turtles in Hai Phong;

+ On July 23, 2019: detected and arrested 7 frozen tigers in Hanoi;

+ On September 14, 2019: detected and arrested 1 living tiger individual on the wayfrom Nghe An to Quang Ninh.

In recent years, Vietnam has been considered as a decisive factor in the prevention and destruction of the wildlife key trade key routeglobally. The Vietnamese government has paid much attention to that matter by strict supervising of law enforcement agencies, amending the Penal Code and enhancing international cooperation... [27]. The Government (GOV) has been aware of the importance of biodiversity values and its potential contribution to national economic development. They have therefore issued a series of regulations on the management and protection of these valuable resources. Since 1994, after becoming a Party to CITES, the GOV have issued many regulations on the harvest and trade of wild fauna and flora in order to facilitate the implementation of the 
Convention. [2]

However, international cooperation and mutual legal assistance in criminal matters seems to be remaining a big challenge.

Mutual legal assistance agreements (MLAT) are an effective tool to deal with transnational organized crime, especially WLFC. The stricter laws regarding the WLFC usually belong to source countries, where cultural symbols are being slaughtered and forests are illegally cut.

In a recent case in South Africa, a Thai citizen was sentenced to 40 years in prison for selling rhino horn, then appealed to reduce the sentence to 30 years in prison. The Thai citizen is believed to be working for a Laotian criminal who has close ties to Vietnam, who is still free.

Lao citizens are beyond the reach of South African authorities due to the absence of MLAT. The same thing can happen with the criminals about WLFC operating in Vietnam and sending others to do their jobs in Africa and the rest of the world. Without MLAT, Vietnam will in fact become a safe haven for these criminals to operate internationally.

Luckily, Vietnam has MLAT with GMS countries; however, the reporters were not provided with any examples of Vietnam extraditing WLFC suspects [19]

3.3.2. Legal framework

Vietnam has promulgated several legal framework to implement Cites Convention namely:

- Law on Forestry in 2017; Law on Biodiversity in 2018; the Government Decree $32 / 2006 / \mathrm{NĐ}-\mathrm{CP}$ on Management of endangered, precious, and rare species of wild flora and fauna, replaced by the Government Decree 06/2019/NĐ-CP on Management of endangered, precious, and rare species of wild flora and fauna and the implementation of Cites Convention took affects since March 10, 2019; the Government Decree 160/2013/NĐ-CP on November 12, 2013 on Criteria to determine species and the regime of managing species under Lists of endangered, precious and rare species prioritized protection of which Article 7 was amended by the Government Decree 64/2019/NĐ-CP on July 16, 2019; The Circular no. 27/2018/TT-BNNPTNT, dated 16/11/2018 on management and traceability of forest products issued by Ministry of Agriculture and Rural Development is available in Vietnamese; The Directive no.05/2018/NQ-HDTP on implementation of the Penal Code on crimes related to wildlife protection, dated 5/11/2018 issued by the Viet Nam Supreme Court is available in Vietnamese [3]; Circular No. 29/2019/TT-BNNPTNT dated December 31, 2019 on handling of forest animals being exhibits; and forest animals voluntarily submitted to the State by organizations and individuals [10]

- The 2015 Penal Code (amended in 2017) prescribed 2 wildlife crimes: Article 234 Offences against regulations on management and protection of wild animals belongs to Chapter XVIII - Economic offences and Article 244 - Offences against regulations on management and protection of endangered, rare animals belongs to Chapter XIX Environmental offences [26]. While Article 234 regulates wildlife offences related to Appendix II or common wildlife, the latter one prescribes wildlife offences related to Appendix I of Cites Convention. Lists of endangered, precious and rare species include 39 flora of group I, 92 fauna of group I, 55 flora of group II, 87 fauna of group II.

- Vietnam has signed international commitments including London Decleration on the Illegal Wildlife Trade in whichGovernments committed to apply or amend legal regulations, in case of necessity, to ensure that illegal wildlife trade is being possessed as serious crimes; The Memorandum of the 3rd International Conference on Combating Illegal Wildlife Trade in 2016, which Vietnam is the host; Bilateral cooperation agreements between Vietnam and some other countries including Laos, South Africa, Campuchia, Indonesia, China, Mozambique; The bilateral cooperation agreements between 
Vietnam and Tanzania, Kenya are discussing; Cooperation statement between Vietnam and the Czech Republic on strengthening coordination to combat illegal wildlife trade.

- Besides, Declaration in APEC Ministerial Meeting in 2014 showed the commitment of participants, in which Vietnam participated, in continuing efforts in combating wildlife trafficking in APEC nations, reducing the supply of and demand for illegally traded wildlife and taking steps to combat wildlife trafficking through enhancing international cooperation and protection.

- Declaration between Vietnam and the United States of America and Environment Chapter of The Comprehensive and Progressive Agreement for Trans-Pacific Partnership (CPTPP) which entered into force for 11 countries stated that each country commits to fully implement CITES Convention and other measures to combat wildlife trafficking and treat wildlife trafficking crimes seriously.

\subsection{Wildlife trafficking's purposes}

The consumers use wildlife products for following main purposes [11]: Producing jewelry, ornaments from parts of wildlife (ivory, tiger fangs...); Designing fashion products from wildlife (reptile or big cats' skin...); Making favorite seafood from sea wildlife (shark fins or marine turtles...) or medicines (scales of pangolins, rhino horns, bear bile, tiger bones...; Providing pets for people or supplyinganimals to the zoos (parrots, tortoises and freshwater turtles, primates...).

\section{Challenges in detecting and handling with wildlife crimes}

\subsection{Legal regulations and its implementation}

- Legal system has been inconsistent with several unclarified definitions. It has been difficult to distinguish between biodiversity conservation farms and commercial farms;

- The Vietnam Penal Code 2015 which has put into effect to reality contains many changes compared to the 1999 one. However, these new regulations and approaches take time to adapt and apply;

- Resources for CITES implementation including resources for policy development, law enforcement, and controlling wildlife-breeding is still limited;

- Social perceptions and needs in the context of unsustainable economic growth has led to the ambiguity between conservation and development, even in policy-making and regulatory documents-making;- There are still contradictions exist in a part of Vietnamese people's culture and awareness namely crowd psychology, insensitivity with society problems including environmental ones as well as "law-abiding and enforcement culture".

\subsection{Inconsistency in investigation measures among countries}

Being used as an investigative technique by many countries, controlled delivery allows detected traffickers "deliver" illicit goods with the intension of uncovering a broader criminal conspiracy. Beside that, police's undercover operations which officers impersonate criminals and infiltrate criminal networks is also a specialized investigative technique in some nations [5]. However, in Vietnam, these two measures are not considered as investigation measures under the 2015 Criminal Procedure Code. In order to collect evidence in wildlife cases, law enforcement authorities have to use other investigation measures. As a consequence, in some cases, only transporters were arrested while crimeline, foreign traffickers or foreign offenders who commit the crimes via Internet were 
not dismantled.

\subsection{Difficulties in species identification}

Th results of species identification play a vital role to criminal authorities as which help to decide whether to use emergency measures to handle evidence orto requestvaluationare necesary or not. Results of species identification are also a reliable source of evidence to support law enforcement officers prosecute or litigate at trial and identify exact offenses and penalties as well.In spite of this, species identification has faced to different obtacles such as i) the lack of wildlife species appraisers and experts, especially in case of flora and fauna that do not exist in Vietnam; ii) dificulties in wildlife specimens protection due to the shortage of modern and specialized equipment at law enforcement operations; iii) very costly because transnational wildlife cases often include many wildlife species and parts, especially those that do not exist in Vietnam. [12] A number of trafficked wilflife species was arrested in Vietnam; however, they was unallocated in Vietnam: Cervus elaphus/Bactrian red deer, Alces alces/Moose, Oryx dammah/Scimitarhorned oryx, Hylobates pileatus...

In some cases, it can not identify species due to the deficiency of research data such as pangolin scales, ivory ; the lack of reproductive parts; or dried specimens causing the difficulties to determine their morphological characteristics [4] DNA database support actively for law enforcement authorities in identifying species at high reliability level as well as wildlife trafficking by its source of seized products. At the same time, DNA database helps us find out wildlife trafficking hotspot, exhausting exploited species to make priority conservation programs and re-released into the nature through traceability [8]. However, DNA establishment has not been focused yet leading to sample specimens limitation for identification

\subsection{Difficulties in detecting, arresting and dealing with sophisticated tricks of transnational wildlife crimes}

It is difficult to identify wildlife crimes because of several reasons ofhigh percentage of wildlife trafficking with different kinds of offenders (professional ones, diplomats, overseas students...), diverse forms of transportation (aviation, road, container, coach, ...) and sophisticated tricks to hide shipments (tying egg sacs to chest, in underwear; hidding in camouflage containers or vehicles, packing it to transfer by coach; hiring others to temporary import for re-export at border gates, making use of rugged mountainous borders to hire others for transportation...). In case of detecting that illicit acts, it seems to be difficult to handle the goods owners and buyers because they often refuse to receive shipments or establish "bogus company" to complete procedures, rent warehouses, assign each participant to receive goods. Therefore, it is unable to determine the owner. For Customs, large quantities of goods make it difficult to control all cargo [11], [6].

For example, in September of 2018, a shipment from Nigeria to Danang on Linda Via IMO 9122345 which has not made customs declaration forms was hidden in container no. MSKU 0147717 under the bill of lading no. 770655775. The name of goods was declared on the emanifest as New Plastic PETS. The company registered on the bill of lading was Thien Truong Su Company Limited (Doan Ket hamlet, Nghia Xuan commune, Quy Hop district, Nghe An province). This company refused to receive goods. Nigeria requested to provide information about Genaral Cargo consignment. Consignors were 2 Nigerian companies and receivers were 2 Vietnamese companies both located in Soc Son district, Hanoi City. They also refused to receive goods. [25]

Besides, recently, wildlife traffickers have used online marketplaces [7] to avoid 
controlling and detecting of authorities.

\subsection{Difficulties in international cooperation and mutual legal assistance in criminal matters}

Differences in regulations and law in mutual legal assistance in criminal matters between Vietnamese and other countriesabout procedure, implementation, time-limit, forms, rights of competent officers... lead to difficulties in implementing mutual legal assistance and time consuming to resolve assistance requests. Moreover, mutual legal assistance treaty that Vietnam has signed with other countries do not specify the time-limit for settling requests for mutual legal assistance in criminal matters, which causes greatly affects the implementation of mutual legal assistance.

In addition, there is no mutual legal assistance treaty signed between Vietnam and several nations, especially African ones, where are still undergoing civil war or underdeveloped () leading to limitation in responding to Vietnam's legal assistance requests.

The mutual legal asisstance in cirminal matters does not exit resulting in untimely coordination and limitation in applying reciprocity principle. It is also hard for Vietnamese authorities to keep in touch with the Central Authorities of the country receiving legal assistance requests so information is mainly exchanged through diplomatic channels. Therefore, the activities of sending dossiers of criminal justice assistance requests, supplementing necessary information, updating progress and settlement encounter meet difficulties.

\subsection{Other challenges}

During the application of Article 234 and Article 244 in Vietnamese Penal Code 2015 (amended in 2017), some entanglements can be seen both in adjudication and reality such as how to determine "body parts indispensable for life" or valuation wilflife animals belonged to Appendix I of Cites Convention.

Besides, that regulations in legal documents do not specify which specialized agencies are responsible for handling wildlife exhibits makes it difficult in exhibits preservation and budget provision for this workin suspended cases.

Lastly, wildlife products are no longer subject to criminal cases of Smuggling or Illegal cross-border transport of goods, they do not fall under the Customs's jurisdiction even though this authority initial directly detects the cases.

\section{Reasons of aforementioned difficulties in detecting and handling wildlife crimes}

First, there have been a number of inconsistencies between Vietnam and other nations' legal framework such as differencies in criminal procedure system or criminalization levels of wildlife crimes.

Second, law enforcement operations have not been fully equipped resources likemodern, specialized equipments, qualified officers and neccessary materials to meet the task's requirements.

Third, there are still law enforcement officers who have been not regularly trained and fostered at specialized institutes causing limited capacity.

Fourth, the signing of Treaties on mutual legal assistance in criminal matters between Vietnam and other countries has been paid attention but still not adequate. ASEAN Treaty 
on mutual legal assistance in criminal matters (ASEAN treaty) prescribes foundamental issues but not specific ones so the Parties base on their domestic laws to reseve several certain contents or articles [14]

Fifth, the legal basis to implement mutual legal assistance is still incomplete in which some are only principled regulations and lack of provisions to regulate legal proceedings related to process of making requests for assistance.

Sixth, different languages in mutual legal assistance is also a barrier as it requires officers with in-depth knowledge of international laws and high-proficient language. Vietnam has few professional translation agencies for less common languages such as the Czech, Polish, Laos or Campuchia [ 13]

Seventh, Treaties on mutual legal assistance in criminal matters that Vietnam has signed with other countries do not contain specific assistance for wildlife crimes such as mutual legal assistance in identifying the origin of wildlife or wildlife products trafficked from abroad to Vietnam.

Eighth, in wildlife cases included foreign elements, it is necesssary to implement mutual legal asisstance to identify goods origin; however, because of various obstacle reasons (conflict of laws, wildlife cases are handled by many agencies through diplomatic channels...), many criminal cases are suspended without final results in the expiry of the time limit for settling under the provisions of the Vietnam's Criminal Procedure Code.

Nineth, inaccurate and unclear translations in implementing mutual legal asisstance leading to unexpected results. At the same time, experiences of officials of investigating bodies, procuracies and courts in Vietnam in the application and implementation of mutual legal assisstance in criminal matters to solve cases are limited while trainings are not timely sufficient provided.

Tenth, evidences obtained from agreements on cooperation in the field of cross-border crime prevention among functional agencies of border provinces of Vietnam, Laos, Campuchia and China; or from Interpol, Aseanpol... are used for further search, information collection to identify whether offense occurred or not and decide appropriate investigation methods. If evidence is not transformed, it can not be used to accuse the offenders. As regulated in the Vietnam's Criminal Procedure Code 2015 and Law of Mutual legal assistance in crinimal matters 2012, the Mutual legal assistance in crinimal matters Department of the Supreme People's Procuracy of the S.R Vietnam is the official channels used to conduct criminal proceedings to collect valuable evidence to prove the crime, the results will be put into the case file to serve as a basis for the conclusion of the investigation, prosecution and conviction criminal cases.

Last but not least, the coordination between frontline forces such as Customs, Forest Protection Department, Border Guards and Investigation Agency and Procuracy for further investigation has not been well implemented.

\section{Recommendations to enhance the efficiency of international cooperation, mutual legal assistance in criminal matters over wildlife crimes}

In order to contribute to timely, accurately detecting, investigating and handling wildlife crimes involving foreign elements or transnational ones, the following solutions are highly recomended:

To sign Bilateral Agreement with each ASEAN country to specify cooperation matters in line with the criminal laws of both countries on handling wildlife crimes;

To keep strenthening the capacity of investigating, prosecuting and adjudicating agencies for transnational wildlife crimes in specialized investigative techniques; measures 
of detecting, seizing, preserving and handling wildlife exhibits; requisition for examination of exhibits and evaluation the results of species identification as well as international cooperation and mutual legal asisstance in criminal matters.

To collaborate with other countries (especially those own trafficked wildlife speciemens) to establish DNA databases for all animals to inspect trading activities and assess trafficked specimens' origin conveniently. To build mechanisms for sharing data from local to national and regional levels with flexible choices for users;To supplement specialized mutual legal asisstance on wildlife crimes in signed mutual legal assistance treaties between Vietnam and other counties of origin of trafficked wildlife, such as mutual legal asisstance in examination of trafficked wildlife or wildlife products' origin from abroad to Vietnam;

To strengthen international cooperation in the context of deep integration, to implement political and international commitments and Hanoi declaration: The Sustainable Development Goals: Turning Words into Action;

To enhance experience exchanges between countries in the field of mutual legal assistance generally and in dealing with wildlife crimes particularly;

To train and foster Vietnamese law enforcement officers in language proficiency and coordination skills in resolving wildlife crimes;

To strenthen coordination relationships among the competent procedural authorities including Customs, Forest Protection Department, Border Guard, Investigation Agency, the Procuracy and the Court for offender identification and classification, evidence collection, investigation, prosecution and adjudication, ect.

To continue organizing trainings for officials of investigating bodies, procuracies and courts on mutual legal assistance in criminal matters generally and wildlife crimes particularly for unified perception in legal assistance. In addition, materials gathering experience in dealing with wildlife crimes included foreign elements and implementing Treaties on mutual legal assistance in criminal matters to support law enforcement agencies to fufill their duty should be developed.

To require the Supreme People's Procuracy of Vietnam continue negotiating and signing mutual legal assistance treaties bteween Vietnam and other countries where wildlife are regularly trafficked;

To propose Central judicial authorities to issue guidelines to determine whether criminal cases included foreign elements need legal assistance's results in order to avoid abuse of institutions, suspending the expiry of the proceeding time and leading to crimes omission.

To supplement the specialized investigative technique "controlled delivery" in Vietnam's Criminal Procedure Code to easily detect and investigate the traffickers;

To propose the Supreme People's Procuracy and Ministry of Public Security of Vietnam delivering more training and fostering for local Prosecutors and Investigators in criminal justice assistance;

To strengthen propaganda, raising awareness and calling for responsibility of community for protecting wildlife and denouncing wildlife crimes.

\section{References}

1. B. Venkataraman. TRAFFIC (2007) (Access date: 17.02.2020) URL: www.traffic.org/publications/reports/a-matter-of-attitude-the-consumption-of-wildanimal-products-in-ha-noi-viet-nam/

2. Ministry of Agriculture and Rural Development. Report on the review of Vietnam's wildlife trade policy, (2008) (Access date: 17.02.2020) URL: www.cites.org/sites/default/files/common/prog/policy/Vietnam_wildlife_trade_policy_ review.pdf 
3. CITES Vietnam $\underline{(2018)}$ (Access date: 19.02.2020) URL: cites.org/sites/default/files/eng/com/sc/71/E-SC71-20.pdf

4. D.D. Phong. Vietnam Cites Management Authority and Central Institute for natural resourses and environmental studies, 25-31 (2018)

5. G. Broussard, K. Pretorius. United Nations Office on Drug and Crime (UNODC) and Hanoi Procuaratorate University (HPU) (2019)

6. Wildlife Smuggling Concealment - Case Study Handbook, 5-39 ( 2015)

7. K. Pretorius, R. Puttonen. Regional Meeting on drafting legislation to combat wildlife crime. United Nations Office on Drug and Crime (UNODC) and Hanoi Procuaratorate University (HPU), 32-35 (2019)

8. L. D. Minh. Meeting report "Solutions to improve the efficiency of coordination and information sharing between scientific agencies and Cites management authority in wildlife assessment in Vietnam".Vietnam Cites - Management Authority and Central Institute for natural resourses and environmental studies, 37-53 (2018)

9. M..T.Romley. Training on Improving effectiveness in the prosecution and supervision over wildlife crimes, 3-15 (2019)

10. Ministry of Agriculture and Rural Development. Circular No. 29/2019/TT-BNNPTNT dated December 31, 2019 on handling of forest animals being exhibits; and forest animals voluntarily submitted to the State by organizations and individuals. (Access date: 19.02.2020) URL: thuvienphapluat.vn/van-ban/EN/Vi-pham-hanhchinh/Circular-29-2019-TT-BNNPTNT-handling-of-forest-animals-being-exhibitsand-forest-animals-voluntarily/434074/tieng-anh.aspx

11. N.A. Tuan. Training on controlling and combating wildlife trafficking, 15-28 (2019)

12. N.D. Hanh. Conference for Guiding the process of wildlife specimens collection and management for assessment (United States Agency for International Development, 11$21(2019)$

13. N.Q. Anh. Conference for Strengthening interdisciplinary justice coordination to prevent and combat wildlife crimes, 15-30 (2018)

14. N.X. Quyen. Conference paper Reality in implementing Law on mutual legal assistance in 2007, 31-40 (2019)

15. C. Nellemann, R. Henriksen et al. The Environmental Crime Crisis - Threats to Sustainable Development from Illegal Exploitation and Trade in Wildlife and Forest Resources (2014) (Access date: 18.02.2020) URL: www.cbd.int/financial/monterreytradetech/unep-illegaltrade.pdf

16. R. Puttonen, G. Broussard. Session 8: International Cooperation - Regional Meeting on drafting legislation to combat wildlife crime, 44-52 (2019)

17. O.R. Rosero. An analysis of the law enforcement chain in the Eastern Tropical Pacific Seascape (2010) (Access date: 18.02.2020) URL: www.issuelab.org/resource/ananalysis-of-the-law-enforcement-chain-in-the-eastern-tropical-pacific-seascape.html

18. TRAFFIC. Rhino horn users: Who are they? (2013) (Access date: 18.02.2020) URL: www.traffic.org/site/assets/files/8094/rhino-horn-consumers-who-are-they.pdf

19. UNODC (2015) (Access date: 18.02.2020) URL: www.unodc.org/documents/southeastasiaandpacific/Publications/wildlife/Vietnam_To olkit_Report_EN_-_final.pdf

20. UNODC (2017) (Access date: 18.02.2020) URL: www.unodc.org/documents/data-andanalysis/wildlife/Research_brief_wildlife_su.pdf 
21. UNODC. Survey Results - Participants from the Regional Meeting on Drafting Legislation Combatting Wildlife Crime - Regional Meeting on drafting legislation to combat wildlife crime (2019)

22. UNODC (2013) (Access date: 18.02.2020) URL: www.unodc.org/documents/data-andanalysis/Studies/TOCTA_EAP_web.pdf

23. UNODC

(Access

date:

19.02.2020)

URL: www.unodc.org/eng/resources/pub/Wildlife_Crime_Analytic_Tookit.pdf

24. UNODC. Wildlife Crime in the Region and Overview of Legal Frameworks - Regional Meeting on drafting legislation to combat wildlife crime (2019)

25. V.T. Manh. Legislation and obligation to implement CITES - Training on controlling and combating wildlife trafficking, 3-14 (2019)

26. Vietnamese National Assembly's. Amended 2015 Penal Code: Law number 100/2015/QH13 and number 12/2017/QH14 (2019). (Access date: 20.02.2020) URL: www.wipo.int/edocs/lexdocs/laws/en/vn/vn086en.pdf; https://vanbanphapluat.co/law12-2017-qh14-amendments-100-2015-qh13

27. WCS Vietnam. Summary report on wildlife violation and law enforcement in Vietnam, period 2013-2017, 10-20 (2018) 